\title{
CLINICAL USE OF STANDARDIZED NAMING INSTRUMENTS FOR EARLY LITERACY SCREENING IN SPEECH AND LANGUAGE THERAPIST PRACTICE
}

Savicka Līga ${ }^{1}$, Riemere Kristīne ${ }^{2}$, Vabale Andra², Vētra Anita²

${ }^{1}$ Riga East Clinical University Hospital - Riga, Latvia

${ }^{2}$ Riga Stradiņš university - Riga, Latvia

BACKGROUND There is a lack of standardized instruments for early literacy screening in Latvia. As we approach the new model of compulsory primary education from the age of six, it is especially important to identify possible difficulties with phonological abilities and literacy. RAN test results correlate with literacy levels (Manis, Doi, Bhadha, 2000).

\section{THE AIM}

To adapt a rapid naming instrument for clinical use in speech therapist practice and illustrate trends of rapid naming in Latvian children from kindergarten and primary schools.

\section{MATERIALS AND METHODS}

Authors have carried out two quantitative, descriptive studies. The participants were 5-12 year old children $(\mathrm{n}=541)$ from general population with Latvian as native language, from 32 educational institutions.

Children were assessed with Rapid automatized naming (RAN) - Rapid alternating stimulus (RAS) test (Denckla M, Rudel R, Wolf M, 2005).

RAN-RAS test, created by Denckla, Rudel and Wolf, is one of the most often used rapid naming tests (Norton, Wolf, 2012).

It can be administered in 10-15 minutes and it is a simple procedure that requires a short, structured training.

RAN test consists of 4 subtests: Objects, Colors, Numbers and Letters. RAS test consists of 2 subtests: Letters and Numbers, Letters, Numbers and Colors.

A child has to name all the visual stimuli on a subtest as fast as possible. Results are measured in the naming time and analyzed according to the age of a child.

Statistical analysis of data was done using IBMS SPSS Statistics 22.

Manis, FR, Doi, LM, Bhadha, B. Naming speed, phonological awareness, and orthographic knowledge in second graders. Journal of Learning Disabilities. 2000, 33(4), 325-33, 374.

Wolf, M, Denckla, R. Rapid Automatized Naming and Rapid Alternating Stimulus Tests. Examiner's Manual. PRO-ED, 2005.

Norton, ES, Wolf, M. Rapid Automatized Naming (RAN) and Reading Fluency: Implications for Understanding and Treatment of Reading Disabilities. Annual Review of Psychology. 2012, 63.-427-52, 431-432.

Riemere, K. Raitas Automatizētas vārdu Nosaukšanas stimultesta (RAN) adaptācija Latvijā piecus un sešus gadus vecu bērnu populācijāa: magistra darbs: specialitāte audiologopēdija. Rīga: Rīgas Stradiņa Universitāte, 2015.

Savicka L. Raitas automatizētas vārdu nosaukšanas un main̄̄go stimulu testa (RAN-RAS) adaptācija Latvijā 7-12 gadus veciem bērniem: magistra darbs: specialitāte

rehabilitācija. Rīga: Rīgas Stradiṇa Universitāte, 2017.

\section{RESULTS}

Children are the quickest in naming RAN Letters and RAN Numbers, rather than RAN Objects and RAN Colors, because these stimuli require attention and visual processing. And even though children learn the names of letters and numbers later, they automatize them better. $32 \%$ of 5 year olds couldn't name RAN Numbers and 58\% couldn't name RAN Letters. Naming times were quicker for RAS 2 stimulus, than RAS 3 stimulus subtest (Diagram 1). RANRAS reliability coefficients in 6-12 year olds are high $(r>0,75, p<.001)$. Internal consistency is high for all subtests and age groups $(\alpha=.93)$.

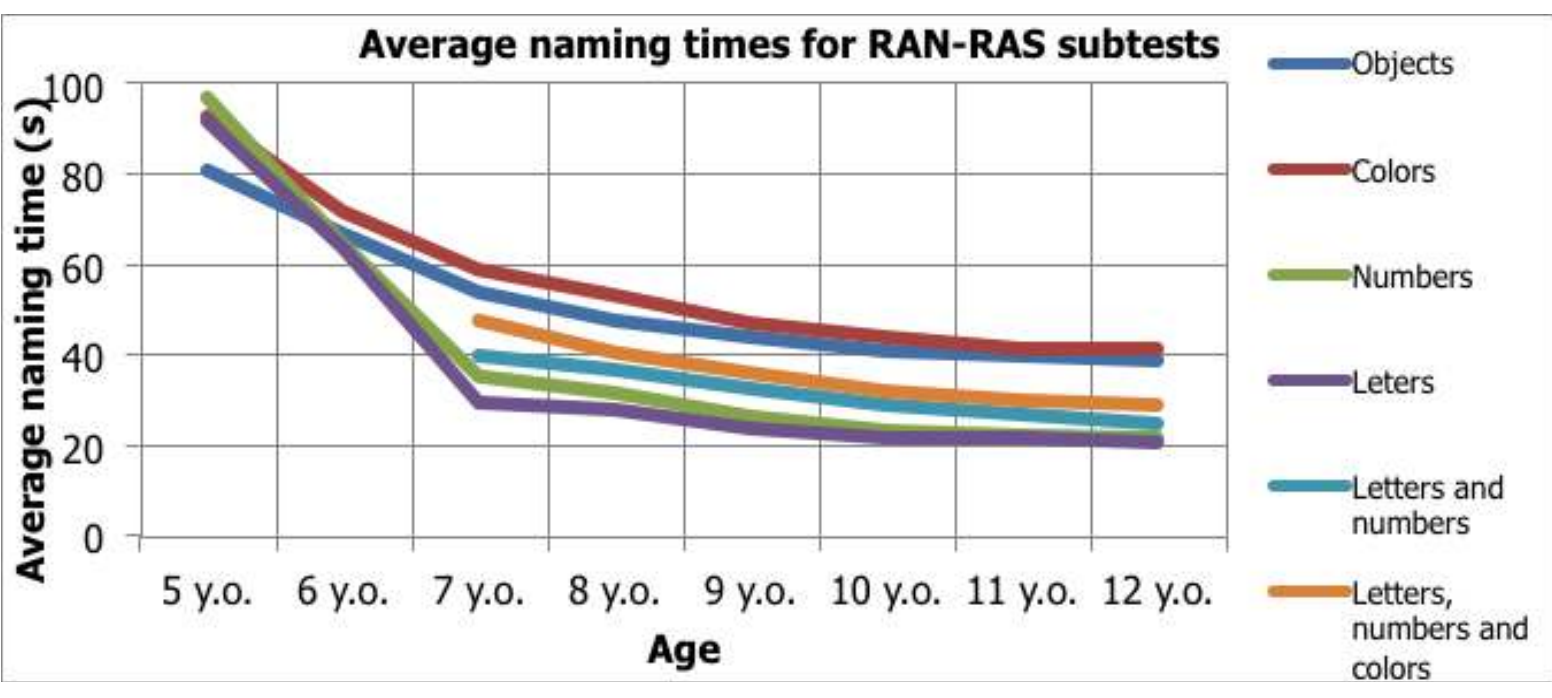

Diagram 1. Average naming times for RAN-RAS subtests.

\section{CONCLUSIONS}

- RAN-RAS test latvian version has been adapted for use for children aged 5-12 (Riemere, Vabale, Vētra, 2015; Savicka, Vabale, Vētra, 2017) and can be recommended for clinical use.

- Based on reliability coefficients and learning process guidelines, it would benefit to use subtests RAN Letters and RAN Numbers for children from the age of six.

TAKE HOME MESSAGE

Latvian RAN-RAS test version can be used for:

a. early screening of literacy and to avoid a wait-and-see approach,

b. starting appropriate and timely

